\title{
Penilaian Intensifikasi PBB P2 dalam Meningkatkan Penerimaan Daerah
}

\author{
${ }^{1}$ Mega Tunjung Hapsari, ${ }^{2}$ Tjahjanulin Domai, ${ }^{3}$ Firda Hidayati \\ ${ }^{1,2,3}$ Fakultas Ilmu Administrasi, Universitas Brawijaya Malang, Indonesia \\ ${ }^{1}$ Email korenpondensi: hapsarimega11@gmail.com
}

Recieved: 20-04-2018 | Revised: 07-05-2018 | Accepted: 24-05-2018

\begin{abstract}
The aims of this research to analyze the assessment of intensification on rural and urban land and building tax (PBB P2) in Tulungagung Regency in order to increase PBB P2 revenue through Davey Analysis based on four criteria of local tax assessment, namely: sufficiency and elasticity, justice, administrative ability, and influence of incentive. This research is classified as descriptive research through qualitative approach. Data analysis used interactive models by Miles, Huberman, and Saldana (2014). The research result based on empirical data, theoretical study, and normative study showed that intensification in the forms of technical guidance and SISMIOP data base maintenance are give negative implication on administrative ability assessment due to lack of quality and quantity of human resources. While, monitoring and delivery of SPPT can give positive implication on judgment of justice. Then, presence of socialization on regional regulation and reward giving and sanction imposition, are give positive implication on assessment of elasticity and influence of incentive.
\end{abstract}

Keywords: Tax Assessment, Intensification, PBB P2.

\begin{abstract}
Abstrak
Tujuan penelitian ini untuk menganalisis penilaian intensifikasi pajak bumi dan banungan perdesaan dan perkotaan (PBB P2) di Kabupaten Tulungagung dalam meningkatkan penerimaan daerah melalui Analisis Davey berdasarkan empat kriteria penilaian pajak daerah, yaitu: kecukupan dan elastisitas; keadilan; kemampuan administratif, dan pengaruh insentif. Penelitian ini tergolong jenis penelitian deskriptif dengan pendekatan kualitatif. Analisis data menggunakan model interaktif Miles, Huberman, dan Saldana (2014). Hasil penelitian berdasarkan dukungan data empiris, kajian teoritis, dan kajian normatif, menunjukan bahwa intensifikasi berupa bimbingan teknis dan pemeliharaan basis data SISMIOP memberikan implikasi negatif pada penilaian kemampauan administratif akibat kurangnya kualitas dan kuantitas sumber daya manusia. Sedangkan pemantauan dan penyampaian SPPT memberikan implikasi positif pada penilaian keadilan.. Kemudian adanya sosialisasi peraturan daerah serta pemberian reward dan sanksi memberikan implikasi positif terhadap penilaian elastisitas dan pengaruh insentif
\end{abstract}

Kata Kunci: Penilaian Pajak, Intensifikasi, PBB P2.

Saran sitasi: Hapsari, M., Domai, T., \& Hidayati, F. (2018). Penilaian Intensifikasi PBB P2 dalam Meningkatkan Penerimaan Daerah. Jurnal Akuntansi dan Pajak, 19(1), 21-30. doi:http://dx.doi.org/10.29040/jap.v19i1.197

DOI: http://dx.doi.org/10.29040/jap.v19i1.197 


\section{Pendahuluan}

Desentralisasi berupa pengalihan kewenangan dari pemerintah pusat kepada pemerintah daerah telah dilakukan di Indonesia sebagai konsekuensi atas kebijakan otonomi daerah yang berdampak pada tantangan fiskal daerah. Tantangan desentralisasi fiskal dalam penguatan kemandirian keuangan daerah ditandai dengan berlakunya Undang-Undang Nomor 33 Tahun 2004 serta Undang-Undang Nomor 23 Tahun 2014, yang memberikan kewenangan seluasluasnya, disertai dengan pemberian hak dan kewajiban menyelenggarakan otonomi daerah dalam kesatuan sistem peyelenggaraan pemerintahan negara. Salah satu kewenangan tersebut berkaitan dengan pengelolaan keuangan daerah yaitu tentang pemungutan pajak daerah dan retribusi daerah.

Pajak daerah selaku sumber keuangan daerah dalam perjalanannya telah mengalami perubahan nomenklatur sebagai upaya untuk meningkatkan penerimaan dan memantapkan kemandirian daerah. Akibatnya, hal tersebut memunculkan adanya reformasi perpajakan daerah yang ditandai dengan diterbitkannya Undang-Undang Nomor 28 Tahun 2009 tentang Pajak Daerah dan Retribusi Daerah. Undang-Undang Pajak Daerah dan Retribusi Daerah telah mengatur pengalihan pajak pusat menjadi pajak daerah, salah satunya yaitu Pajak Bumi dan Bangunan Perdesaan dan Perkotaan (PBB P2). Pajak bumi dan bangunan menurut Bell dan Brunori (2014) merupakan sumber pendapatan daerah yang paling penting. Berdasarkan data statistik, kontribusi PBB secara Nasional sebelum proses pendaerahan pada tahun 2014 memiliki prosentase sebesar 21,23\% (Badan Pusat Statistik, 2013). Setelah PBB P2 resmi dialihkan kepada pemerintah daerah, maka
$100 \%$ hasil penerimaan PBB P2 dapat menjadi peluang dan tantangan tersendiri bagi pemerintah daerah untuk meningkatkan penerimaan dan kemandirian daerah. Untuk menjawab tantangan dan peluang tersebut, Pemerintah Kabupaten Tulungagung melalui Badan Pendapatan Daerah (Bapenda) menggunakan strategi intensifikasi dalam menggenjot penerimaan PBB P2. Namun, hasil rekapitulasi penerimaan PBB P2 Kabupaten Tulungagung mulai tahun 2014-2017 cenderung dibawah jumlah potensi PBB P2 yang dapat diterima, sebagaiman yang tertuang dalam Tabel 1, maka penilaian dan perbaikan upaya intensifikasi sangat dibutuhkan dalam meningkatkan penerimaan PBB P2 di Kabupaten Tulungagung.

Hasil penelitian Gaffney (2009) menilai bahwa penggalian potensi pajak tanah dan bangunan memiliki kontribusi positif terhadap penerimaan pajak daerah. Namun penggalian potensi tersebut memerlukan usaha yang besar, ketelatenan, dan strategi yang tepat agar dapat memaksimalkan penerimaannya. Senada dengan hal tersebut, hasil penelitian Oktifauziah dan Idayati (2014) serta Yuniarti, dkk (2016), merujuk pada sebuah kesepakatan bahwa elastisitas dalam pemungutan pajak, keadilan, dan kemampuan administratif, merupakan faktor yang mempengaruhi peningkatan penerimaan PBB P2. Di sisi lain, hasil penelitian Dewi dan Maulida (2012); Siahaan, dkk (2013); Nurhayati (2015); Padang, dkk (2016), menemukan beberapa hambatan yang sering muncul dalam intensifikasi pajak daerah diantaranya: rendahnya tingkat kesadaran wajib pajak; kurangnya kapasitas dan kapabilitas petugas pajak; kurangnya kerjasama antar stakeholder terkait untuk meningkatkan penerimaan pajak; serta lemahnya sistem dan mekanisme administrasi pajak.

Tabel 1 Prosentase Realisasi Penerimaan PBB P2 Kabupaten Tulungagung terhadap Potensi Tahun 2014-2017

\begin{tabular}{ccccc}
\hline No. & Tahun & Potensi & Realisasi Penerimaan & Persentase \\
\hline 1 & 2014 & 23.514 .718 .388 & 23.436 .249 .062 & 99,66 \\
2 & 2015 & 24.178 .725 .736 & 24.166 .771 .682 & 99,95 \\
3 & 2016 & 25.295 .595 .264 & 25.493 .683 .398 & 100,78 \\
4 & 2017 & 27.421 .152 .222 & 27.056 .181 .455 & 98,66 \\
\hline
\end{tabular}

Sumber: Badan Pendapatan Daerah, (2018). 
Masalah pajak wilayah perdesaan menurut Davey (1988) biasanya banyak berkutat pada potensi-potensi yang belum diinventarisir dan kekuatan masyarakat untuk memenuhi pajak tersebut. Davey mengungkapkan untuk menilai potensi pajak sebagai penerimaan daerah diperlukan beberapa kriteria, seperti: (1) Kecukupan dan Elastisitas; (2) Keadilan; (3) Kemampuan Administrasi; dan (4) Pengaruh Insentif. Dengan adanya penilaian berdasarkan kriteria tersebut, akan memberikan manfaat untuk mengetahui seberapa besar potensi PBB-P2 yang bisa diperoleh oleh pemerintah daerah, kecukupan realisasi pajak terhadap target dalam PAD, serta pemecahan masalah terkait pemungutan dan pengelolaan PBB-P2.

Berdasarkan latar belakang diatas, penelitian ini bertujuan untuk menganalisis penilaian intensifikasi PBB-P2 di Kabupaten Tulungagung dalam meningkatkan penerimaan daerah. Penilaian potensi PBB-P2 dilakukan menggunakan kriteria penilaian perpajakan daerah menurut Davey (1988). Adapun hasil penelitian ini secara akademis diharapkan mampu memberikan kontribusi bagi pengembangan ilmu pengetahuan dan sebagai bahan referensi yang berkaitan tentang penilaian pajak daerah khususnya PBB $\mathrm{P} 2$, intensifikasi, serta peningkatan penerimaan daerah. Sedangkan kontribusi praktis penelitian ini dapat digunakan sebagai bahan evaluasi bagi Pemerintah Daerah Kabupaten Tulungagung khususnya Bapenda atas pelaksanaan intensifikasi untuk meningkatkan penerimaan PBB P2.

\section{Tinjauan Pustaka}

\section{Intensifikasi Pajak Daerah}

Pengertian Intensifikasi Pajak Menurut Surat Edaran Direktorat Jenderal Pajak Nomor SE06/PJ.9/2001 tentang Pelaksanaan Ekstensifikasi Wajib Pajak dan Intensifikasi Pajak, menyatakan bahwa: "Intensifikasi pajak adalah kegiatan optimalisasi penggalian penerimaan pajak terhadap objek serta subjek pajak yang telah tercatat atau terdaftar dalam administrasi Direktorat Jenderal Pajak". Intensifikasi pajak daerah dan retribusi daerah sebagai suatu usaha yang dilakukan oleh pemerintah kabupaten/kota untuk meningkatkan penerimaan pajak daerah dan retribusi daerah yang biasanya diaplikasikan dalam bentuk: (1) Perubahan Tarif Pajak dan retribusi daerah; (2) Peningkatan pengelolaan pajak dan retribusi daerah.

\section{Pajak Bumi dan Bangunan Perdesaan dan Perkotaan (PBB P2)}

Pajak properti atau pajak bumi dan bangunan merupakan pajak yang bersifat kebendaan atau pajak yang bersifat objektif dalam arti besarnya pajak yang terutang ditentukan oleh keadaan objek yaitu bumi/tanah dan atau bangunan (Widodo,). Pemungutan pajak bumi dan bangunan tersebut berlaku pada wilayah perdesaan dan perkotaan. Yang dimaksud perdesaan merupakan objek PBB dalam suatu wilayah yang memiliki ciri-ciri perdesaan, seperti: sawah, ladang, empang tradisional, dan lain-lain. Sedangkan perkotaan merupakan objek PBB dalam suatu wilayah yang memiliki ciri-ciri suatu daerah perkotaan, seperti: pemukiman penduduk yang memiliki fasilitas perkotaan, real estate, kompleks, industri, perdagangan dan jasa. Dasar pengenaan PBB P2 adalah NJOP (Nilai Jual Objek Pajak). NJOP didefinisikan sebagai harga rata-rata yang diperoleh dari transaksi jual beli yang terjadi secara wajar NJOP ditetapkan setiap 3 (tiga) tahun, kecuali untuk objek pajak tertentu dapat ditetapkan setiap tahun sesuai dengan perkembangan wilayah dan ditetapkan dengan peraturan daerah.

\section{Kriteria Penilaian Pajak Daerah}

Potensi pendapatan sektor pajak dari suatu daerah berbeda-beda disebabkan oleh faktor demografi, ekonomi, sosiologi, budaya geomorfologi dan lingkungan dari daerah tersebut, tidak terkecuali pendapatan pajak daerah. Menurut Davey (1988) terdapat empat kriteria umum yang dapat digunakan untuk menilai pajak daerah, yaitu sebagai berikut:

1) Kecukupan dan elastisitas: Kecukupan dan elastisitas merupakan persyaratan pertama yang harus dipenuhi yaitu bahwa sumber pendapatan tersebut harus menghasilkan pendapatan yang lebih besar dibandingkan dengan seluruh atau sebagian biaya pela- 
yanan yang akan dikeluarkan. Pajak diharapkan menunjukkan elastisitasnya, yaitu pertama pertumbuhan potensi dari dasar pengenaan pajak itu sendiri, kedua kemudahan untuk memungut pertumbuhan pajak tersebut.

2) Keadilan: Prinsipnya yaitu beban pengeluaran pemerintah harus ditanggung semua golongan dalam masyarakat sesuai dengan kekayaan dan kesanggupan masing-masing golongan.

3) Kemampuan Administrasi: Pemajakan tanah menuntut dua persyaratan yang berat, pertama yaitu pencatatan rinci mengenai hak milik, nilai, dan peruntukannya. Kedua, kondisi tentang ukuran dan ciri dari tubuh pemilikan tanah. Kejujuran diuji dalam kappasitas administrasi dimana ketika bertatap muka dengan wajib pajak dan penilaian tanah untuk menetapkan nilai objek pajak selanjutnya. Kemudian juga berkaitan dengan kemampuan dan keterampilan sumber daya manusia dalam melakukan pemungutan dan pengelolaan pajak.

4) Pengaruh Insentif: Perpajakan mempunyai tujuan ganda; yaitu pertama menyediakan dana untuk kepentingan umum, dan kedua mempengaruhi tingkah-laku ekonomi melalui pemberian insentif.

\section{Metode Penelitian}

Jenis penelitian dalam penelitian ini adalah deskriptif dengan pendekatan kualitatif. Sugiyono (2014) menjelaskan bahwa metode penelitian kualitatif adalah metode penelitian yang berlandaskan filsafat postpositivisme, digunakan untuk meneliti pada kondisi obyek alamiah, dimana peneliti adalah sebagai instrumen kunci, teknik pengumpulan data dilakukan melalui observasi, wawancara mendalam dengan teknik snowball sampling, dan dokumentasi, analisis data bersifat induktif. Adapun analisis data pada penelitian ini menggunakan model interaktif Miles, Huberman, dan Saldana (2014) melalui kondensasi data, penyajian data, serta pengambilan dan verifikasi kesimpulan.

\section{Hasil dan Pembahasan}

Pemungutan dan pengelolaan PBB-P2 oleh pemerintah daerah Kabupaten Tulungagung telah dilaksanakan sejak 1 Januari 2014. Sampai dengan tahun 2017, pemungutan dan pengelolaan PBB-P2 terus dioptimalkan melalui upaya intensifikasi. Namun, pada pelaksanaannya, muncul berbagai macam tantangan dan permasalahan. Untuk itu, melalui empat kriteria umum penilaian pajak daerah menurut Khennet Davey, penelitian ini berhasil menganalisis penilaian intensifikasi PBB P2 Kabupaten Tulungagung berdasarkan kecukupan dan elastisitas, keadilan, kemampuan administrasi, dan pengaruh insentif dalam pemungutan dan pengelolaan PBB-P2 di Kabupaten Tulungagung, sebagai berikut:

\section{Kecukupan dan Elastisitas}

Untuk menilai kecukupan dan elastisitas dari Potensi PBB P2 Kabupaten Tulungagung, terdapat beberapa indikator menurut Davey (1988) yang bisa digunakan sebagai acuan. Indikator-indikator untuk penilaian kecukupan dan elasititas pajak tersebut diantaranya adalah sebagai berikut:

1) Kecukupan dan elastisitas dapat mempengaruhi pertumbuhan potensi dari dasar pengenaan pajak itu sendiri;

2) Kemudahan untuk memungut pertumbuhan pajak;

3) Kepekaan keputusan yang diambil atau tuntutan atas kemampuan administrasi;

4) Perbandingan hasil penerimaan selama beberapa tahun dengan perubahan-perubahan dalam indeks harga, penduduk atau Produk Nasional Bruto;

5) Pertumbuhan yang otomatis dalam potensi pajak terlepas dari keputusan untuk mengubah tarif pajak.

Sebelumnya penerimaan PBB-P2 Kabupaten Tulungagung periode 2010-2013 menunjukkan penerimaan yang terus mengalami tren penurunan. Dari Rp23.420.209.800,00 pada tahun 2010 menurun sebesar $4,84 \%$ pada tahun 2011 menjadi Rp22.286.172.565,00. Peningkatan tipis terjadi pada tahun 2012 yaitu sebesar 0,23\% menjadi Rp22.338.082.286,00. Kemudian terjadi 
penurunan sebesar $6,42 \%$ terjadi pada tahun 2013 menjadi hanya Rp20.903.879.404,00.

Namun, setelah dilakukan proses pendaerahan, PBB-P2 relatif mengalami peningkatan penerimaan. Hasil rekapitulasi penerimaan PBB P2 Kabupaten Tulungagung pada tahun 20142017 memperlihatkan bahwa persentase perolehan realisasi melebihi target Anggaran Pendapatan dan Belanja Daerah (APBD) setiap tahunnya. Namun, hasil persentase tersebut secara fluktuatif masih belum mencapai jumlah potensi penerimaan yang bisa diperoleh. Adapun hasil rekapitulasi penerimaan PBB-P2 sebagaiamana Tabel 2.

Penerimaan PBB-P2 tahun 2014 sebesar Rp 23.436.249.062,00 meningkat $10,82 \%$ dibandingkan dengan realisasi pungutan PBB-P2 tahun 2013 yang sebesar Rp 20.903.879.404,00. Kemudian Pendapatan Asli Daerah (PAD) Kabupaten Tulungagung khususnya dari PBB-P2 meningkat pada tahun pertama pelaksanaan pendaerahan PBB-P2, yakni target PBB-P2 dalam APBD 2014 sebesar Rp 22 miliar terealisasi berkisar $\mathrm{Rp} \operatorname{Rp}$ 23.436.249.062,00 atau $106,53 \%$ dari target yang ditentukan. Pada tahun 2015 penerimaan PBB-P2 tercapai 105,07\% dari target Rp 23 milliar. Tahun 2016 penerimaan PBB-P2 tercapai 104,06\% dari target Rp 24,5 milliar. Sedangkan tahun 2017 penerimaan PBB-P2 tercapai 103,27\% dari target Rp 26,2 milliar.

Berdasarkan data realisasi pada Tabel 2, penerimaan PBB-P2 Kabupaten Tulungagung mampu memberikan kecukupan dalam pembiayaan daerah. Hal ini dikarenakan penerimaan PBB-P2 mampu melampau target APDB setiap tahunnya. Namun, hasil realisasi realisasi tersebut relatif belum mencapai target potensi PBB P2. Artinya, masih terdapat celah untuk Bapenda
Kabupaten Tulungagung dalam meningkatkan penerimaan sesuai potensi yang bisa didapatkan.

Dari segi elastisitas, Bapenda Kabupaten Tulungagung melalui upaya intensifikasi telah melalukan Sosialisasi Peraturan Daerah Kabupaten Tulungagung Nomor 17 Tahun 2016 tentang Perubahan Kedua atas Perda Nomor 16 Tahun 2010 tentang Pajak Daerah, serta Peraturan Bupati Tulungagung Nomor 5 Tahun 2017 tentang Perubahan atas Peraturan Bupati Nomor 26 Tahun 2013 tentang Petunjuk Pelaksanaan Pemungutan PBB P2 di Kabupaten Tulungagung, yang memberikan dampak positif bagi masyarakat. Dalam hal ini, sosialisasi dilakukan melalui kerjasama dengan Desa/ Kelurahan serta melalui pemanfaatan media masa, media sosial, dan media elektronik. Adanya sosialisasi perda tentang P2 membuat masyarakat lebih sadar dalam kewajiban membayar PBB P2, semakin responsif terhadap perubahan dalam tata cara pembayaran PBB P2 serta dalam pemanfaat pelayanan pada Unit Pelaksana Teknis Badan (UPTB) yang telah disediakan oleh Bapenda Kabupaten Tulungagung. Setelah dilakukan sosialisasi, terbukti jumlah wajib pajak yang membayar PBB P2 semakin meningkat. Tentu saja hal tersebut memberikan dampak positif bagi peningkatan penerimaan PBB P2.

Sebagai usaha keberlanjutan atas sosialisasi yang telah dilakukan, Bapenda Kabupaten Tulungagung terus melakukan perbaikan dan upaya lebih dalam meningkatkan pelayanan PBB P2 melalui elastisitas atau kemudahan dalam membayar pajak. Bapenda telah melakukan upaya kemudahan dalam pelayanan PBB P2 diantaranya mulai dari Kantor Pelayanan Satu Tempat (PST) hingga bekerja sama dengan Bank Konvensional. Dalam hal ini, kantor pelayanan telah tersebar di seluruh Kecamatan se-

Tabel 2 Hasil Rekapitulasi Penerimaan PBB P2 Kabupaten Tulungagung Tahun 2014-2017

\begin{tabular}{cccccc}
\hline No. & Tahun & Potensi & Target APBD & Realisasi & Persentase \\
\hline 1 & 2014 & 23.514 .718 .388 & 22.000 .000 .000 & 23.436 .249 .062 & 106.53 \\
2 & 2015 & 24.178 .725 .736 & 23.000 .000 .000 & 24.166 .771 .682 & 105.07 \\
3 & 2016 & 25.295 .595 .264 & 24.500 .000 .000 & 25.493 .683 .398 & 104.06 \\
4 & 2017 & 27.421 .152 .222 & 26.200 .000 .000 & 27.056 .181 .455 & 103,27 \\
\hline
\end{tabular}

Sumber: Bapenda Kabupaten Tulungagung, 2018 
Kabupaten Tulungagung serta memiliki jaringan ATM yang luas. Hal tersebut dimaksudkan agar masyarakat lebih mudah menjangkau tempat pembayaran PBB P2.

Tidak hanya berhenti pada pelayanan melalui kantor PST dan Bank, terdapat pelayanan tambahan yaitu tempat pembayaran PBB P2 melalui mobil keliling. Bapenda menyediakan dua unit mobil keliling ini sebagai upaya peningkatan pelayanan pembayaran PBB P2 bagi masyarakat yang berlokasi jauh dari bank tempat pembayaran. Dengan berbagai fasilitas serta kemudahan tersebut, merupakan suatu elastisitas untuk membuat masyarakat sebagai wajib PBB P2 lebih taat dalam memenuhi kewajibannya dalam membayar pajak. Dengan demikian, hasil penelitian ini mendukung hasil penelitian sebelumnya yang telah dilakukan oleh Oktifauziah dan Idayati (2014) serta Yuniarti, dkk (2016), yaitu menemukan bahwa elastisitas dalam pemungutan pajak merupakan salah satu faktor yang mempengaruhi peningkatan penerimaan PBB P2.

\section{Keadilan}

Keadilan merupakan salah satu penilaian penting untuk menilai pemungutan dan pengelolaan pajak. Terdapat beberapa indikator yang dapat digunakan sebagai penilaian dari keadilan pajak. Adapun indikator-indikator yang dapat digunakan untuk menilai keadilan dalam pemungutan dan pengelolaan pajak menurut Davey (1988) adalah sebagai berikut:

1) Pemerataan secara vertikal-hubungan dalam pembebanan pajak atas tingkat pendapatan yang berbeda-beda;

2) Keadilan horizontal-hubungan pembebanan pajak dengan sumber pendapatan;

3) Keadilan secara geografis-pembebanan pajak harus adil antar penduduk di berbagai daerah;

4) Perpajak progresif dikehendaki berdasarkan pertimbangan keadilan sosial. Artinya, kelompok berpendapatan paling rendah harus dikenakan pajak yang paling ringan atau dibebaskan sama sekali dari pungutan pajak.

Penilaian keadilan pada intensifikasi PBB

P2 Kabupaten Tulungagung dilakukan melalui analisis sistem reward dan sanksi. Penerapan sistem ini digunakan untuk meningkatkan kepatuhan dan kesadaran wajib pajak dalam membayar PBB P2, serta sistem ini juga dimaksudkan sebagai bentuk pemerataan bagi wajib pajak dengan memberikan intensif maupun disintensif dalam pembayaran PBB P2. Adanya pemberian reward dan sanksi diharapkan mampu memberikan rasa keadilan dan kepastian hukum bagi wajib pajak dengan membayar PBB P2 sesuai dengan pengklasifikasian fungsi objek pajak yang dimiliki. Di sisi lain, pemberian sanksi adalah bentuk pengawasan pada intensifikasi penerimaan pajak. Sebab sanksi merupakan salah satu alat pencegah (preventif) agar wajib ajak tidak melanggar norma perpajakan.

Keadilan dan kepastian hukum dalam membayar pajak merupakan azas dalam pemungutan pajak. Azas equality atau azas keadilan dalam pemungutan pajak menekankan pada keadilan bagi wajib pajak dengan membayar PBB P2 sesuai dengan pengklasifikasian fungsi objek pajak yang dimiliki. Sejalan dengan penelitian yang telah dilakukan oleh Nusa, dkk (2017), nilai keadilan dapat terlihat pada perbandingan pembayaran pajak yaitu harus disesuaikan dengan kondisi masyarakat (tidak dapat dipukul rata). Kemudian, pemerintah tidak boleh melakukan diskriminasi antara sesama wajib wajib. Artinya, dalam keadaan yang sama, para wajib pajak harus dikenakan pajak yang sama pula. Berdasarkan hal tersebut, Bapenda Kabupaten Tulungagung menggunakan sistem pemungutan PBB P2 melalui Official Assesment System, dimana wewenang untuk menentukan besarnya pajak yang terutang melalui Surat Pemberitahuan Pajak Terhutang (SPPT) terletak pada fiskus atau pegawai pemungut pajak. Dalam hal ini wajib pajak bersifat pasif, karena hutang pajak baru timbul setelah dikeluarkannya surat ketetapan pajak oleh fiskus. Official Assesment System digunakan oleh Bapenda Kabupaten Tulungagung berdasarkan pertimbangan beberapa alasan. Adapun alasan penggunaan sistem tersebut berdasarkan hasil wawancara penelitian adalah agar pemerintah daerah bisa melakukan klasi- 
fikasi pembatasan dalam pemungutann pajak. Hal tersebut diperlukan karena untuk menilai obyek pajak tidak bisa sembarangan orang, artinya membutuhkan orang dengan keahlian khusus yang betul-betul mengerti dan paham cara menilai obyek pajak sesuai dengan ketentuan peraturan. Berbeda dengan self assessment system dimana wewenang untuk menentukan besarnya pajak terletak pada pihak wajib pajak yang bersangkutan, dalam PBB P2 tidak bisa dilakukan seperti itu. Kemudian Official Assesment System juga merupakan salah satu bentuk kontrol dari pemerintah Kabupaten Tulungagung dalam memungut dan mengelola PBB P2.

Selanjutnya azas certainty atau azas kepastian hukum menekankan pada pajak yang dibayar oleh wajib pajak harus pasti dan tidak mengenal kompromis antara wajib pajak dan pegawai pajak. Dalam azas certainty ini, kepastian hukum yang dipentingkan adalah mengenai subjek PBB P2, objek PBB P2, dan ketentuan mengenai waktu pembayaran. Berdasarkan hal tersebut, reward diberikan berupa undian berhadiah tiap tahun bagi wajib pajak yang patuh dan tepat waktu dalam pembayaran pajak sedangkan sanksi diberikan berupa kenaikan sebesar $2 \%$ per bulan bagi wajib pajak yang terlambat membayar. Adapun undian berhadiah yang diberikan berupa sepeda motor, sepeda gunung, peralatan elektronik, dan banyak bingkisan yang lainnya.

\section{Kemampuan Administratif}

Penilaian pajak selanjutnya adalah terkait kemampuan administratif. Kelly (2000) menyebutkan bahwa terdapat enam fungsi utama dari administrasi sistem pengelolaan pajak bumi dan bangunan, yaitu: basis data pajak, penilaian pajak, pemungutan pajak, keadilan pajak, penyelesaian sengketa, serta layanan wajib pajak. Kemampuan para pegawai pajak dalam mengelola basis data serta pemberian bimbingan teknis sangat krusial dalam hal ini. Permasalahan yang terjadi adalah bimbingan teknis merupakan agenda program kerja tahunan, namun program bimbingan teknis tersebut belum mampu memberikan peningkatan kinerja yang tepat sasaran dalam pelaksanaan strategi intensifikasi penerimaan PBB P2. Bimbingan teknis pada pemeliharaan basis data SISMIOP (Sistem Manajemen Informasi Objek Pajak) baru menghasilkan dua orang pegawai yang memiliki sertifikat pengawas/penilai obyek pajak. Akibatnya, kekurangan sumber daya manusia tersebut membuat pembaruan data Nilai Jual Obyek Pajak (NJOP) yang seharusnya rutin dilakukan tiga tahun sekali atau setahun sekali bagi wilayah tertentu sesuai Surat Keputusan Bupati Tulungagung Nomor: 188.45/436/2014 tentang Penentuan Klasifikasi dan Besarnya Nilai Jual Obyek Pajak sebagai Dasar Pengenaan Pajak Bumi dan Bangunan Perdesaan dan Perkotaan menjadi lambat sehingga tidak sesuai dengan harga pasar. Jelas hal ini tidak memberikan dampak positif bagi penerimaan PBB P2, sebab hal tersebut memicu hilangnya potensi peningkatan penerimaan pajak berdasarkan kenaikan NJOP akibat keterlambatan dalam pembaruan data. Temuan tersebut sejalan dengan hasil penelitian terdahulu yang telah dilakukan oleh Dewi dan Maulida (2012); Siahaan, dkk (2013); Nurhayati (2015); dan Padang, dkk (2016) yang menemukan beberapa hambatan yang sering muncul dalam intensifikasi pajak daerah diantaranya: kurangnya kapasitas dan kapabilitas petugas pajak, serta lemahnya sistem dan mekanisme administrasi pajak, sehingga hal tersebut dapat menghambat peningkatan penerimaan pajak.

Menurut data BPS Kabupaten Tulungagung tahun 2018, jumlah desa dan kelurahan di Kabupaten Tulungagung adalah sebanyak 271 terbagi atas 257 desa dan 14 kelurahan. Jumlah pengawas untuk penilaian obyek pajak hanya 2 orang. 1 orang pengawas membawahi 4 orang petugas lapangan. 1 petugas lapangan menilai obyek pajak pada 1 desa. Untuk menilai obyek pajak 1 desa diperlukan waktu kurang lebih 4 bulan. Sehingga dengan jumlah 2 orang pengawas yang membawahi 8 petugas lapangan maka dapat melakukan penilaian obyek pajak pada 8 desa selama 4 bulan. Sehingga dapat diamsu/sikan dalam satu tahun penilaian obyek pajak pada pemeliharaan basis data SISMIOP hanya 
menjangkau kurang lebih 24 desa. Apabila pembaruan ketetapan NJOP menurut peraturan dilakukan 3 (tahun) sekali, maka maksimal pemeliharaan hanya terjadi pada 72 desa atau $26 \%$ dari total desa yang mengalami perubahan NJOP. Berdasarkan hal tersebut, implikasi yang terjadi adalah NJOP menjadi tidak sesuai dengan harga pasar. Dengan demikian dapat disimpulkan bahwa BAPENDA Kabupaten Tulungagung kehilangan potensi penerimaan PBB P2 kurang lebih sebesar $74 \%$ setiap jadwal perubahan NJOP akibat keterbatasan dalam pemeliharaan basis data SISMIOP.

\section{Pengaruh Insentif}

Menurut Davey (1988), pengaruh insentif merupakan salah satu cara yang dapat dilakukan untuk melakukan penilaian pajak daerah. Insentif merupakan salah satu bentuk reward yang diberikan oleh Bapenda kepada petugas pemungut. Semenjak pendaerah PBB-P2, terdapat konsekuensi bahwa pemerintah daerah tidak lagi menerima dana untuk biaya pemungutan PBB P2 karena tidak lagi menerima dana bagi hasil PBBP2 dari pemerintah pusat. Sebagai gantinya maka diberikan insentif pemungutan sesuai dengan Peraturan Pemerintah Nomor 69 Tahun 2010 tentang Tata Cara Pemberian dan Pemanfaatan Insentif Pemungutan. Menurut Peraturan Pemerintah Nomor 69 Tahun 2010 pasal 5, sumber dana dari insentif ini berasal dari pendapatan Pajak dan Retribusi sesuai dengan ketentuan peraturan perundang-undangan. Besarnya insentif pemungutan sebelum pendaerah PBB P2 adalah sebesar 9\%, namun besarnya insentif pemungutan pasca pendaerah PBB P2 yang ditetapkan oleh Pemerintah Kabupaten Tulungagung adalah sebesar 5\% dari rencana penerimaan pajak daerah dalam Anggaran Pendapatan dan Belanja Daerah tahun anggaran berkenaan. Hal ini bisa diartikan bahwa dasar dari besaran nominal 5\% tersebut tergantung dari target. Apabila PBB P2 sudah mencapai target penerimaan, maka akan disisihkan sebesar 5\% untuk biaya pemungutan.

Penganggaran insentif pemungutan untuk aparat Kecamatan, Kelurahan dan Desa diambil sebesar 5\% dari 5\% jika memenuhi pencapaian target penerimaan PBB P2. Maksud dari besaran nominal 5\% dari 5\% tersebut ialah, total penerimaan PBB P2 dikalikan 5\% setelah itu hasilnya akan dikalikan 5\% lagi untuk insentif pemungutan. Menurut Peraturan Pemerintah Nomor 69 Tahun 2010 Pasal 4 ayat (1) insentif pemungutan diberikan apabila sudah mencapai kinerja tertentu, yaitu pencapaian target penerimaan PBB P2 yang telah ditetapkan dalam Anggaran Pendapatan dan Belanja Daerah.

Adanya perbedaan nominal tersebut tentunya juga berdampak bagi pendapatan para petugas pemungut, mengingat sistem pemberian insentif ini juga sebagai tambahan penghasilan bagi mereka. Atas dasar tersebut, maka Pemerintah Kabupaten Tulungagung memberikan biaya penyampaian SPPT kepada petugas pemungutan, kebijakan ini dibuat untuk memberikan tambahan penghasilan kepada petugas pemungutan. Kebijakan untuk memberikan biaya penyampaian SPPT dan biaya rekonsiliasi penerimaan PBB P2 tersebut diatur dalam Keputusan Bupati Tulungagung Nomor: 188.45/63/013/2014 yang kemudian telah diperbarui menjadi Keputusan Bupati Tulungagung Nomor: 188.45/42/013/2018 tentang Pemberian Biaya Penyampaian Surat Pemberitahuan Pajak Terhutang dan Rekonsiliasi Penerimaan Pajak Bumi dan Bangunan Perdesaan dan Perkotaan di Kabupaten Tulungagung.

Besaran biaya penyampaian SPPT yang diberikan kepada petugas pemungutan yang pada tahun 2014 sampai dengan tahun 2015 berdasarkan Keputusan Bupati Tulungagung Nomor: 188.45/63/013/2014 adalah sebesar Rp 1.000,00 ditambah dengan biaya rekonsiliasi penerimaan PBB P2 sebesar 1.000,00. Kemudian pada tahun 2016 nomimal insenif tersebut bertambah menjadi sebesar Rp1.500,00 untuk penyampaian SPPT kepada wajib pajak per lembar, dan Rp1.500,00 untuk rekonsiliasi penerimaan PBB P2 atau realisasi dari SPPT yang disampaikan. Sementara itu, untuk proses pemberiannya berdasarkan ketentuan yang berlaku, yaitu untuk penyampaian SPPT kepada Wajib Pajak apabila 
potongan SPPT/Struk PBB-P2 telah diterima kembali oleh Bapenda Kabupaten Tulungagung, maka petugas pungut berhak menerima imbalan sesuai dengan ketentuan yang berlaku.

Pemberian insentif untuk petugas pemungut PBB P2 merupakan suatu bentuk penghargaan atas usaha yang telah dilakukan dalam mengumpulkan pelunasan SPPT. Insentif tersebut menjadi motivasi agar petugas pemungut lebih giat dalam melaksanakan pekerjaannya. Sesuai dengan hasil penelitian Yuda, dkk (2015), dimana tujuan insentif adalah sebagai reward atas kinerja yang telah dilakukan oleh peugas pemungut berdasarkan target yang telah ditetapkan. Sehingga insentif bukan semata-mata untuk memberikan kesejahteraan bagi para petugas pemungut, melainkan juga untuk meningkatkan realisasi penerimaan PBB P2. Dengan demikian, peningkatkan kinerja petugas pemungut melalui pemberian insentif dapat memberikan implikasi positif terhadap peningkatan penerimaan PBB P2.

\section{Kesimpulan}

Berdasarkan hasil kajian dapat disimpulkan bahwa intensifikasi PBB P2 dalam hal penilaian kecukupan, Kabupaten Tulungagung telah mampu memberikan kecukupan dalam pembiayaan daerah berdasarkan hasil realisasi penerimaan PBB-P2 yang mampu melampaui target ABPD tahun 2014-2017. Meski hasil realisasi penerimaan PBB P2 telah melampaui target APBD, namun masih terdapat potensi yang bisa dimaksimalkan. Untuk intensifikasi berupa bimbingan teknis dan pemeliharan basis data SISMIOP, memberikan implikasi negatif pada penilaian kemampuan administratif akibat lemahnya bimbingan teknis sehingga kurang menghasilkan sumber daya manusia yang mumpuni. Kemudian intensifikasi berupa pemantauan dan penyampaian SPPT mampu memberikan implikasi positif pada penilaian keadilan berdasarkan official assesement system dalam penyampaian SPPT. Selanjutnya, adanya sosialisasi peraturan daerah serta pemberian reward dan sanksi memberikan implikasi positif terhadap penilaian elastisitas dan pengaruh insentif. Elastisitas, berupa kemudahan dalam pembayaran PBB-P2 melalui sosialisasi peraturan daerah, tersedianya Unit Pelaksana Teknis Badan (UPTB) yang bekerja sama dengan Bank konvensional, serta terdapat mobil keliling untuk menjangkau masyarakat kesulitan dalam melakukan pembayaran PBB P2. Sedangkan pemberian reward berupa insentif kepada petugas pemungut dapat memotivasi kinerja petugas pemungut sehingga memberikan implikasi positif terhadap peningkatan penerimaan PBB P2.

\section{Ucapan Terimakasih}

Dalam penelitian ini, peneliti menyadari bahwa telah banyak mendapat bantuan, dukungan, dan kesempatan dari berbagai pihak. Oleh sebab itu, peneliti menyampaikan ucapan terima kasih yang sebesar-besarnya kepada Badan Pendapatan Daerah Kabupaten Tulungagung, para informan, dan semua pihak yang telah membantu dalam proses penelitian ini. Peneliti berharap hasil penelitian ini dapat memberikan sumbangan berarti bagi perkembangan ilmu pengetahuan dan pihak-pihak yang membutuhkan.

\section{Daftar Pustaka}

Badan Pendapatan Daerah. (2018). Kabupaten Tulungagung.

Badan Pusat Statistik. (2013). On Line. Diakses melalui: https://www.bps.go.id/.

Bell, Michael and David Brunori. (2014). Symposium On Developing A Property Tax Expenditure Budget. Journal Public Finance and Management 14 (2) 110-117.

Davey, Khenneth. (1988). Pembiayaan Pemerintah Daerah: Praktek-praktek Internasional dan Relevansinya Bagi Dunia Ketiga. Jakarta: Universitas Indonesia Press.

Dewi, Maya Safira dan Maulida, Mirza. (2012). Evaluasi Ekstensifikasi dan Intensifikasi Pajak Serta Kontribusinya Dalam Meningkatkan Penerimaan Pajak Penghasilan Orang Pribadi Pada KPP Pratama Jakarta Tanah Abang Dua. Binus Bussiness Review 3 (1): 228-245.

Gaffney, Mason. (2009). The Hidden Taxable Capacity of Land: Enough and to Spare. 
International Journal of Social Economics 36 (4): 328-411.

Kelly, R. (2000). Designing a Property Tax Reform Strategy for Sub-Saharan Africa: An Analytical Framework Applied To Kenya. Journal of Public Budgeting \& Finance 20 (4): 36-51.

Miles, Matthew B., A. Michael Huberman, dan Johnny Saldana. (2014). Qualitative Data Analysis: A Methods Sourcebook. 3rd Edition. United States Of America: Sage Publications.

Nurhayati, Neni. (2015). Pengaruh Intensifikasi dan Ekstensifikasi Pajak dan Retribusi Daerah terhadap Peningkatan Pendapatan Asli Daerah Dengan Dimoderasi Pelaksanaan Good Governance pada Kabupaten/ Kota di Wilayah III Cirebon. Jurnal Riset Akuntansi dan Keuangan 1 (1): 49-63.

Nusa, A; dkk. (2017). Potensi Pajak dan Retribusi Daerah di Kabupaten Yahukimo. Jurnal Kajian Ekonomi dan Keuangan Daerah 2 (3) 1-19.

Oktifauziah dan Idayati. (2014). Penilaian Intensifikasi dan Ekstensifikasi untuk Meningkatkan Pendapatan Daerah. Jurnal Ilmu dan Riset Akuntansi 3 (1): 1-10.

Padang, dkk. (2016). Intensifikasi Pemungutan Pajak Hiburan sebagai Salah Satu Cara dalam Meningkatkan Pendapatan Pajak
Daerah Kota Malang. Jurnal Perpajakan (JEJAK) 10 (1): 1-8.

Siahaan, dkk. (2013). Analisis Kegiatan Intensifikasi dan Hubungannya dengan Peningkatan Penerimaan Wajib Pajak Orang Pribadi di KPP Pratama Pasar Rebo Jakarta. Jurnal Ilmiah Buletin Ekonomi 17 (2): 20-26.

Sugiyono. (2014). Metode Penelitian Kuantitatif Kualitatif Dan R\&D. Bandung: Alfabeta.

Surat Edaran Direktorat Jenderal Pajak Nomor SE-06/PJ.9/2001 tentang Pelaksanaan Ekstensifikasi Wajib Pajak dan Intensifikasi Pajak.

Undang-Undang Nomor 28 Tahun 2009 tentang Pajak Daerah dan Retribusi Daerah.

Widodo, Puspita Andrea. (2010). Pajak Bumi dan Bangunan Untuk Para Praktisi. Jakarta: Mitra Wacana Media.

Yuda, dkk. (2015). Analisis Pemberian Insentif Pemungutan Pajak Bumi dan Bangunan Sektor Pedesaan dan Perkotaan Setelah Menjadi Pajak Daerah. Jurnal Perpajakan 4 (1): 1-10.

Yuniarti, dkk. (2016). Potensi Pajak Bumi Dan Bangunan Sektor Perdesaan Dan Perkotaan (Studi Kasus Di Kabupaten Malang Ditinjau Dari Perbedaan Harga Pasar Wajar Dengan Nilai Jual Objek Pajak Bumi Yang Berlaku). Jurnal Perpajakan (JEJAK) 8 (1): 1-10. 